$$
\begin{aligned}
& \text { NATS } A=T M-100221 \\
& \text { CONF-880241--3 }
\end{aligned}
$$

NASA Technical Memorandum 100221

\title{
Progress Toward the Evolution of a Stirling Space Engine
}

Donald L. Alger

Lewis Research Center

Cleveland, Ohio

Prepared for the

1988 International Congress and Exposition

sponsored by the Society of Automotive Engineers, Inc.

Detroit, Michigan, February 29-March 4, 1988

\section{NRSA}




\section{DISCLAIMER}

This report was prepared as an account of work sponsored by an agency of the United States Government. Neither the United States Government nor any agency Thereof, nor any of their employees, makes any warranty, express or implied, or assumes any legal liability or responsibility for the accuracy, completeness, or usefulness of any information, apparatus, product, or process disclosed, or represents that its use would not infringe privately owned rights. Reference herein to any specific commercial product, process, or service by trade name, trademark, manufacturer, or otherwise does not necessarily constitute or imply its endorsement, recommendation, or favoring by the United States Government or any agency thereof. The views and opinions of authors expressed herein do not necessarily state or reflect those of the United States Government or any agency thereof. 


\section{DISCLAIMER}

Portions of this document may be illegible in electronic image products. Images are produced from the best available original document. 


\section{DISCLAIMER}

This report was prepared as an account of work sponsored by an agency of the United States Government. Neither the United States Government nor any agency thereof, nor any of their employees, makes any warranty, express or implied, or assumes any legal liability or responsibility for the accuracy, completeness, or usefulness of any information, apparatus, product, or process disclosed, or represents that its use would not infringe privately owned rights. Reference herein to any specific commercial product, process, or service by trade name, trademark, manufacturer, or otherwise does not necessarily constitute or imply its endorsement, recommendation, or favoring by the United States Government or any agency thereof. The views and opinions of authors expressed herein do not necessarily state or reflect those of the United States Government or any agency thereof. 


\title{
PROGRESS TOWARD THE EVOLUTION OF A STIRLING SPACE ENGINE
}

\author{
Donald L. Alger \\ National Aeronautics and Space Administration \\ Lewis Research Center \\ Cleveland, Ohio 44135
}

\section{SUMMARY}

Following the successful testing of the 25 kWe Space Power Demonstrator (SPD) engine in 1985, a Stirling Space Engine (SSE) technology advancement program was initiated. The program's objective was to advance free-piston Stirling engine/alternator technology sufficiently so that a Stirling engine system may become a viable candidate for space power applications.

Evolution of the SSE technology is planned to occur at three different engine heater temperature levels: 650, 1050, and $1300 \mathrm{~K}$. These temperatures define three phases of technology development with the first phase involving the $650 \mathrm{~K}$ SPD engine. Technology development of the $650 \mathrm{~K}$ engine and preliminary design of the $1050 \mathrm{~K}$ engine will be discussed in this paper.

\section{INTRODUCTION}

The National Aeronautics and Space Administration is embarked upon a Stirling space Engine (SSE) technology improvement program. The intent of the program is to advance free-piston Stirling engine/linear alternator component and engine technology sufficiently so that a Stirling engine system may become a viable candidate for space power applications. The SSE program is a part of the SP-100 Advanced Technology Program which ultimately leads toward a $1300 \mathrm{~K}$ free-piston Stirling Space Power system.

The objective of the SSE program is to develop technology necessary to produce a free-piston Stirling engine/linear alternator system that will operate at a heater temperature of $1300 \mathrm{~K}$ and reject heat to a space radiator at a temperature of $650 \mathrm{~K}$. Achievement of this goal will be the culmination of a three phase technology development program evolving engine technology at three different heater temperatures: 650, 1050, and $1300 \mathrm{~K}$.

The first phase of this technology program began with the design, fabrication, and testing of the $650 \mathrm{~K}$ Space Power Demonstrator (SPD) engine, an engine that has caused a dramatic advancement in free-piston stirling technology. Extensive testing of the SPD engine has served to define needed improvements in the design of some engine components.

Division of the opposed-engine SPD into two single-engine test-bed space Power Research (SPR) engines has now allowed component development testing with two SPR engines--one at Mechanical Technology Inc. (MTI) at Latham, New York and the other at NASA Lewis. These SPR engines have been used to improve the engine components. For example, an hydrodynamic bearing system for the SPR engine's power piston is being developed which utilizes a high torque permanent magnet electric motor to spin the piston. A modular heat exchanger design for eventual use in an advanced $1050 \mathrm{~K}$ Experimental Stirling Space (ESS) engine is being designed and will be fabricated and then tested on an 
SPR engine. Construction of a Linear Alternator Development Laboratory is underway by MTI. New alternator structural support configurations will be developed in this laboratory for testing in SPR engines. All of these activities are directed toward the improvement of Stirling engine component technology for input into the design of the $1050 \mathrm{~K}$ engines--the engines of the second phase of the SSE technology development program.

Procurement activity is currently in progress toward the award of a major contract to carry out the second phase of the SSE program--a 4-year technology development program. At least two ESS engines will be fabricated and tested during this program. Included in the 4-year program will be completion of the conceptual design of a $1300 \mathrm{~K}$ engine, prepared in readiness for the start of the third phase of the SSE program.

This paper concentrates on the component technology of the $650 \mathrm{~K}$ SPD (and SPR) engines and the preliminary design of the $1050 \mathrm{~K}$ ESS engines.

\section{SPACE POWER DEMONSTRATOR (SPD) ENGINE}

During 1984, under a contract from NASA Lewis, Mechanical Technology Inc. (MTI), of Latham, New York, designed, fabricated, and began low pressure testing of the $25 \mathrm{~kW} \mathrm{SPD}$ engine, all in less than 16 months. This effort represented a considerable advancement of free-piston Stirling technology. The initial electrical power output of the SPD engine was 4 kWe. Since that time, with increase in helium working fluid pressure and minor modifications to engine components, the engine has developed over $25 \mathrm{~kW}$ of PV power.

As shown in the cut-a-way drawing of figure 1, the SPD engine is actually two free-piston Stirling engine/alternators constructed in an axially opposed configuration. Configured in this manner, the two opposed engines are designed to counterbalance the dynamic forces developed by the displacers and pistons. During SPD operation, accelerometers mounted on the engine housing have measured maximum amplitudes (peak-to-peak) of less than $0.01 \mathrm{~mm}$ which corresponds to a " $g$ " of less than 0.2. A photograph of the SPD engine is shown in figure 2. The engine is suspended from the ceiling by a flexible suspension. The engine is about $1-1 / 4 \mathrm{~m}$ in length and about $1 / 3 \mathrm{~m}$ in diameter. A general description of the engine is given in references 1 and 2 .

Since the first low pressure testing of the SPD engine in June of 1985, several modifications have been made to both the engine and load to increase engine power. These changes include substitution of a sintered screen matrix regenerator for a loose-screen regenerator, modification of the hydrostatic bearing gas flow system, and removal of a redundant current protection device. At the completion of performance testing of the SPD engine, the engine developed about $25 \mathrm{~kW}$ of PV power and $17 \mathrm{~kW}$ of electrical power. Figure 3 shows the relationship between engine and alternator power as a function of piston amplitude under the conditions of 150 bar pressure, $100 \mathrm{~Hz}$ frequency, and at a temperature ratio of two. The alternator efficiency is considerably lower than the design goal of 93 percent. The actual efficiency ranges from about 70 percent at $100 \mathrm{~Hz}$ to the high eighties at $70 \mathrm{~Hz}$. Following completion of performance testing of the SPD engine, the engine was divided to produce two SPR engines. 


\section{SPACE POWER RESEARCH (SPR) ENGINES}

Two SPR engines, SPRE-1 and SPRE-II, were derived from the opposed-piston SPD engine, by cutting the SPD engine into two pieces to produce half of an SPD engine as shown in figures 4 and 5 . Based upon computer predictions, two design modifications were made to the SPR engines that increased the power output slightly in comparison to the SPD engine: (1) a reduction in expansion space volume in the SPR engine relative to the SPD engine, and (2) use of tighter seal clearances in the SPR engine's displacer assembly. To produce a pressure vessel for the single-piston SPR engine, a closure plate was welded to the cut-end of the half-SPD engine. The closure plate was designed to reduce the volume of the expansion space of the SPR engine relative to the expansion space volume of the SPD engine. The result of performance testing of SPRE-I is shown in figure 6. Following these tests, the SPRE-I was installed in a cell at NASA Lewis Research Center and is being used as a testbed engine for component technology development. SPRE-II is being utilized in a similar manner at MTI.

The SPR engines are unbalanced engines that must be attached to a large seismic mass or vibration absorber to reduce the vibration amplitude of the engine casing to acceptable levels. Initially, while development of a vibration absorber was in progress, SPRE-I was attached to an approximate 2-ton mass to reduce the peak-to-peak vibration amplitude of the casing to about 3 mils. Figure 5 is a photograph showing SPRE-I on test while attached to the seismic mass. The vibration absorber that is intended for use with the SPR engines is shown in figure 7 while being tested on a Ling shaker.

\section{COMPONENT DEVELOPMENT WITH SPR ENGINES}

Both SPR engines are being used as test-bed engines to develop engine components for use in the advanced Stirling Space Engines. The following component development activities are currently in progress:

\section{Alternator Development}

SPRE-II engine components were used by MTI to perform alternator diagnostic tests to define alternator losses. With the piston/plunger held fixed to prevent its motion, the stator coil was electrically energized while, one-byone, the alternator structural elements were removed and the change in electrical power required to energize the coil was measured. This change in electrical power was a measure of the power loss in that particular element. In this manner, the power loss associated with all alternator structural elements was measured. Figure 8 lists the structural elements that were tested and illustrates the effect of this power loss upon engine efficiency.

\section{Hydrodynamic Bearing}

Development of the piston hydrodynamic bearing system is being accomplished in parallel with the alternator work because several of the same engine elements are common to both bearing system and alternator. For example, the laminations of the inner stator were not uniform over the circumference of the stator. This caused a cogging effect that made rotation of the 
piston/plunger difficult. The modified SPRE-II uses a uniform inner stator. Rotation of the piston/plunger is accomplished with a permanent magnet electrical motor. Figure 9 is a photograph showing a low pressure (ambient air) hydrodynamic bearing test in progress.

\section{Heat Exchanger Module}

The design of a modular heat exchanger of the type that will be used on the advanced Stirling Space Engine is underway. The heat exchanger will use a sodium heat pipe to transport heat from a common heat source into each module. The overall heat exchanger, consisting of about 20 such modules, will then be fabricated and tested on an SPR engine. Data from these tests will be used for the design of actual Stirling Space Engine Heat exchangers.

\section{STIRLING SPACE ENGINE (SSE) TECHNOLOGY DEVELOPMENT PROGRAM}

\section{Conceptual Design of an Experimental Stirling Space (ESS) Engine}

The start of the second phase of the SSE program began with the conceptual design of the ESS engine by Sunpower of Athens, Ohio. The ESS engine is a single-piston, single-displacer design using an adaptive dynamic balance unit to minimize forces transmitted to the support structure. A drawing of the engine is shown in figure 10. The ESS engine includes several significant technology advances over the SPD engine. Figure 11 lists these advances. Some ESS engine design parameters are listed in figure 12.

\section{ESS Engine}

A major contract will be awarded for the design, fabrication, and testing of at least two ESS engines. Early in the contract period, preliminary designs of the ESS engine, configured as a single-piston engine and as an opposedpiston engine (similar to the SPD engine), will be prepared. The two engine configurations will then be evaluated and compared on the basis of the ability of each engine configuration to best meet the objective of the SSE program. Following this assessment, only one of the engine configurations--either the single-piston ESS engine design or the opposed-piston ESS engine design--will be selected for fabrication of the ESS engines of the SSE program.

The conceptual design of the single-piston ESS will be the starting point for the contract effort. The single-piston ESS engine heat exchanger is made up of 40 heat exchanger modules. Each module consists of a heater, regenerator, and cooler encased in a single tubular structure. Heat pipes, using sodium working fluid, will be used to transfer heat from the heat source into the heat exchanger module heater. A pumped loop may be used to reject heat from the heat exchanger module cooler. A typical heat exchanger module is shown in figure 13. Figure 14 illustrates how a heat pipe may be integrated into the heater section of the module. Complete heat exchanger modules will be flow-tested under both steady state and oscillatory flow to verify design parameters.

Hydrodynamic gas bearings will be used to support all three reciprocating components (displacer, power piston, and balance unit piston). 
The second phase of the SSE program is expected to be concluded with the fabrication of an Endurance Stirling Space (ENSS) engine. The design of the ENSS engine will be based upon an upgraded ESS engine design that was achieved by technology advancements derived from ESS engine testing. The ENSS engine will incorporate space system-compatible heat input, heat rejection, power conditioning, and engine control systems. To complete this phase of the program, the ENSS engine is expected to be given an $8000 \mathrm{hr}$ endurance test.

\section{HIGH TEMPERATURE STIRLING SPACE (HTSS) ENGINE}

The HTSS engine will be designed to have a heater temperature of $1300 \mathrm{~K}$ and a cooler temperature of $650 \mathrm{~K}$. During the second phase of the SSE program, the conceptual design of the HTSS engine will be carried out to serve as a guide for the development of components, materials, and joining processes needed before actual design and fabrication of the engine can take place. The HTSS engine design will serve as the baseline for the start of the third phase of the SSE program--design, fabrication, and testing of the $1300 \mathrm{~K}$ engine.

\section{SCALING STUDY}

Large amounts of electrical power are expected to be needed for space applications with future space platforms requiring hundreds to thousands of kilowatts. Free-piston Stirling engine/alternator systems operated to date (the SPD engine) have only generated power levels of the order of $10 \mathrm{kWe} / \mathrm{cylin}$ der. Clearly, it is important to determine the feasibility of fabricating such an engine with electrical output of the order of $100 \mathrm{kWe} / \mathrm{cylinder}$ or better.

A contract has been awarded to MTI, and considerable work has already been completed, in a scaling study work effort to investigate whether singlecylinder free-piston Stirling engine/linear alternator systems can be designed in the 100 to $150 \mathrm{kWe} / \mathrm{cylinder}$ power range. Relationships between engine efficiency, engine specific mass, temperature ratio, and power output will also be determined. The study will cover a power range between $25 \mathrm{kWe}$ through $150 \mathrm{kWe} /$ cylinder and a temperature ratio range from 1.7 to 3.0. Recommendations will be made, if appropriate, for configurations other than single-cylinder engines with linear alternators (i.e., hydraulic, etc.). If, during the study, it becomes apparent that single cylinder power levels greater than 150 kWe appear to be feasible, an option of the study is to define the design of an engine capable of producing the maximum power per cylinder. Some initial design requirements for the free-piston Stirling engine/linear alternator are: (1) a heater wall temperature of $1050 \mathrm{~K}$, (2) a design life of $60000 \mathrm{hr}$, (3) the use of helium as the working fluid, and (4) a specific mass range of 5 to $8 \mathrm{~kg} / \mathrm{kWe}$. Figure 15 outlines the scope of the work being considered under this study.

CONCLUDING REMARKS

The first phase of the three phase Stirling Space Engine technology improvement program is nearly completed with the successful testing of the $650 \mathrm{~K}$ SPD engine at a nominal PV power output of $25 \mathrm{~kW}$, operating at a 
frequency of $100 \mathrm{~Hz}$ at a temperature ratio of two. The two SPR engines that have been derived from the opposed-piston SPD engine are being used to advance the linear alternator, gas bearings, and heat exchangers of the engines and to provide design data for the second phase Stirling Space Engines.

A major contract will soon be awarded by NASA to carry out an approximate 4-year effort for the second phase of the SSE technology improvement program. At least two Experimental Stirling Space (ESS) engines will be fabricated and test. The heater heads of these engines will operate at a temperature of $1050 \mathrm{~K}$. Heat transport into the heater head will be by heat pipe. Final engine testing is expected to involve an $8000 \mathrm{hr}$ endurance test of an advanced engine identified as the Endurance Stirling Space (ENSS) engine. A preliminary design of a $1300 \mathrm{~K}$ free-piston Stirling engine/linear alternator will also be completed during this second phase to guide the advancement of technology sufficiently so that a $1300 \mathrm{~K}$ engine can be fabricated and tested during the third phase of the SSE program.

A scaling study is nearing completion to determine the feasibility of a 100 to $150 \mathrm{kWe} / c y l i n d e r$ free-piston Stirling engine/alternator system. Engines of this size are expected to be needed to generate the large amounts of electrical power needed for future space platforms.

A clear path for engine and component technology development has been defined that is expected to provide free-piston Stirling engine/linear alternator technology advancements necessary for the engine to become a viable candidate for space power applications.

\section{REFERENCES}

1. G.R. Dochat, "Free-Piston Stirling Engine for Space Power," Twenty-Second Automotive Technology Development Contractor's Coordination Meeting, Society of Automotive Engineers, Warrendale, PA, 1984, pp. 209-213.

2. J.G. Slaby, "Overview of Free-Piston Stirling SP-100 Activities at the NASA Lewis Research Center," NASA TM-87224, 1986. 


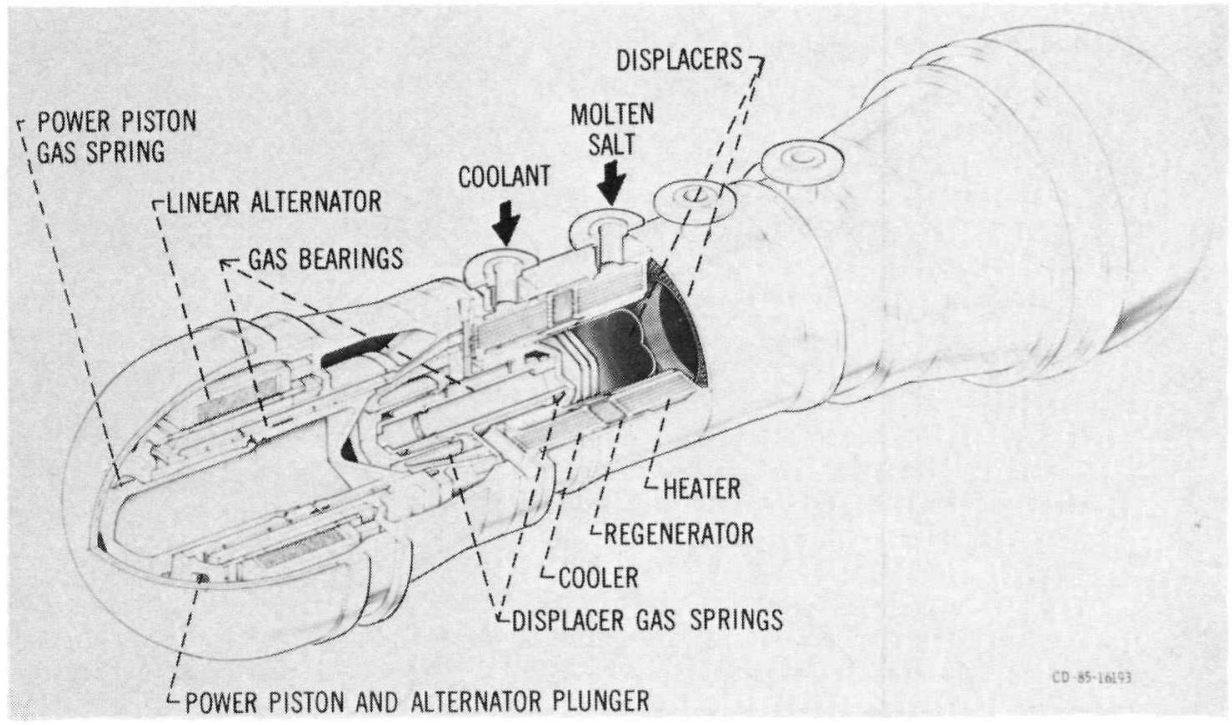

FIGURE 1. - SPACE POWER DEMONSTRATOR ENGINE.

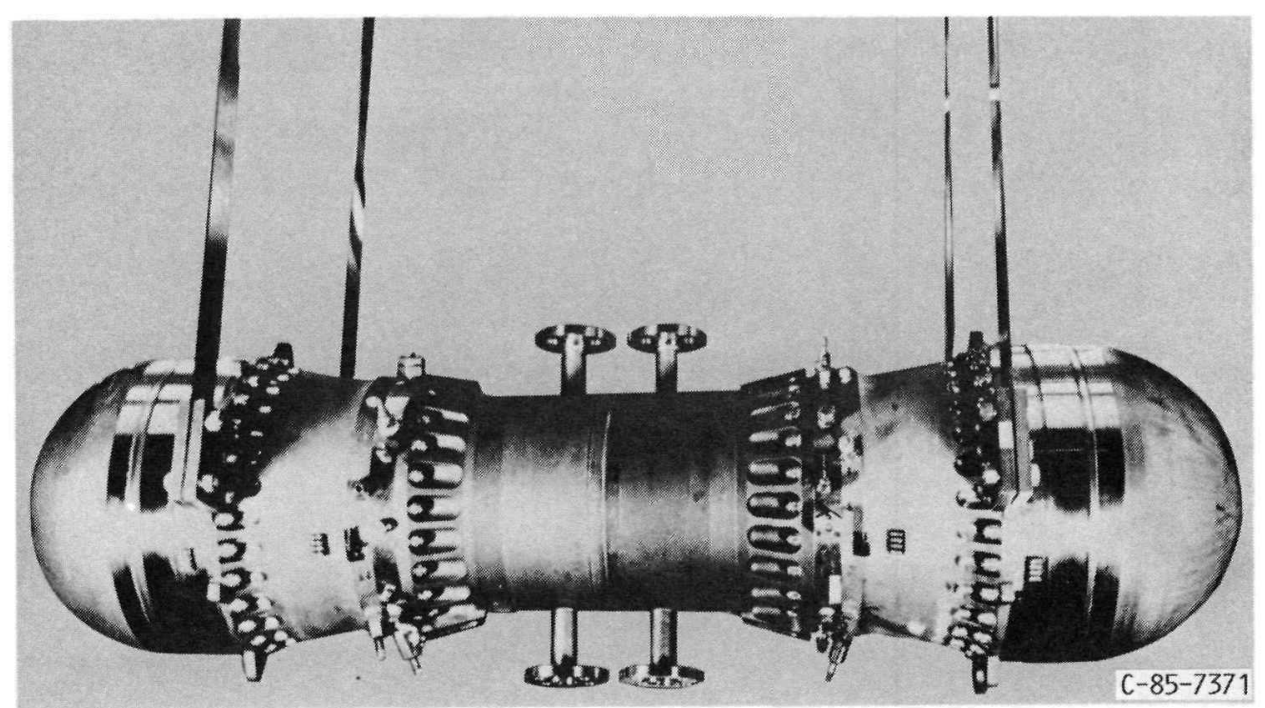

FIGURE 2. - 25 KWE SPACE POWER DEMONSTRATOR ENGINE (SPDE) AT MECHANICAL TECHNOLOGY INC. 


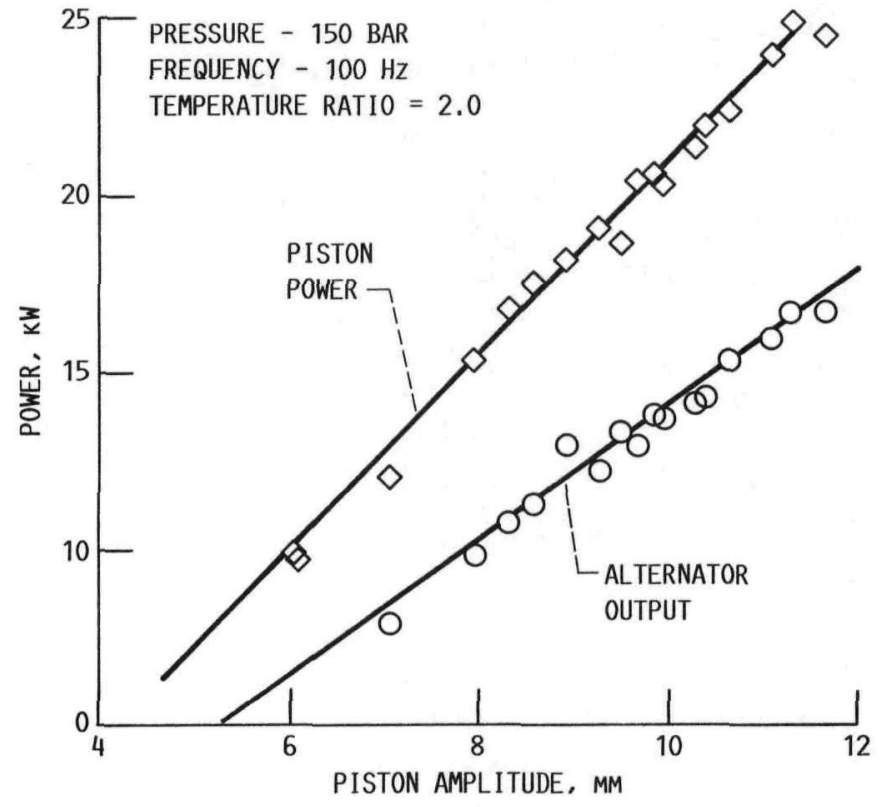

FIGURE 3. - SPDE ENGINE TESTS - OCTOBER 24. 1986.

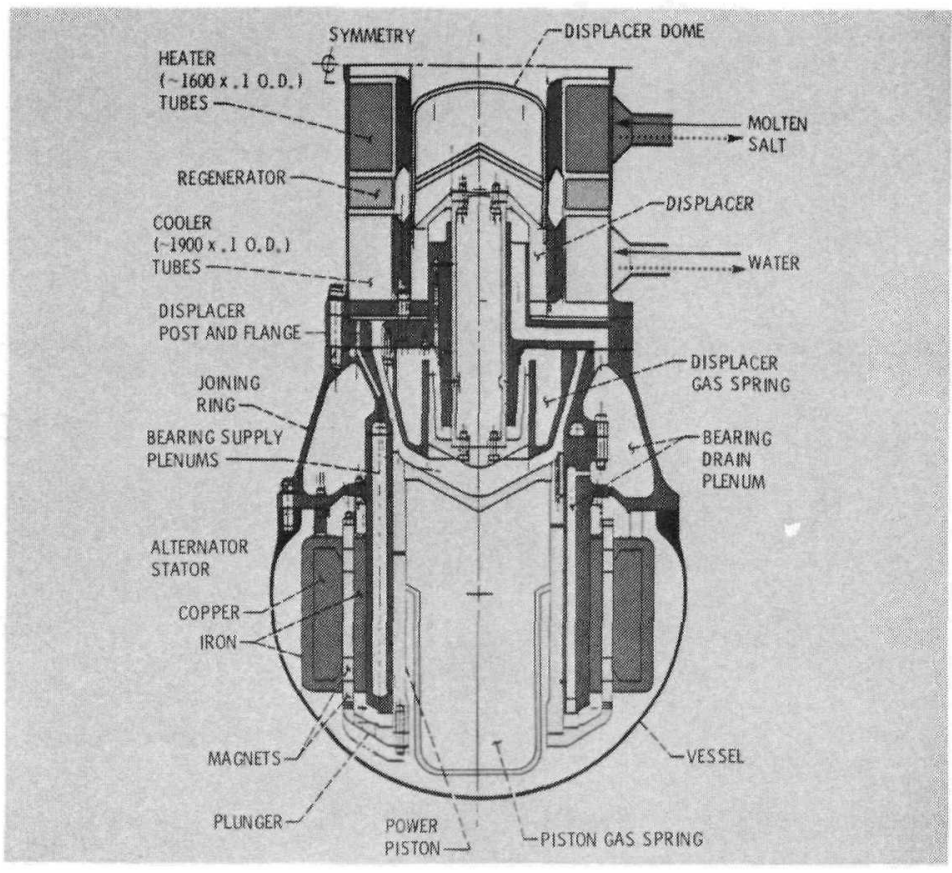

FIGURE 4. - HALF OF 25 KWE SPDE. 


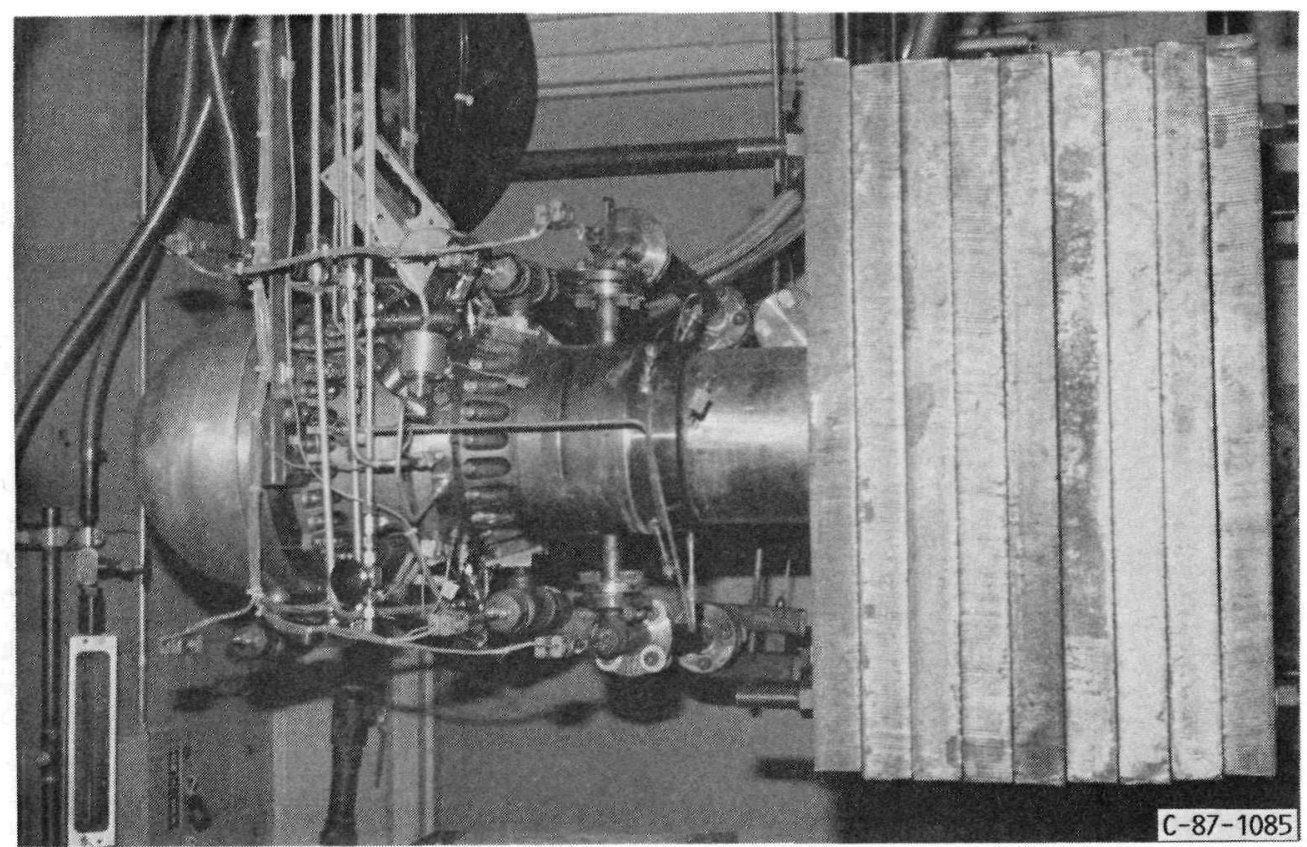

FIGURE 5. - SPRE-I ON TEST. 2-TON SEISMIC MASS ATTACHED TO REDUCE VIBRATION AMPLITUDE.

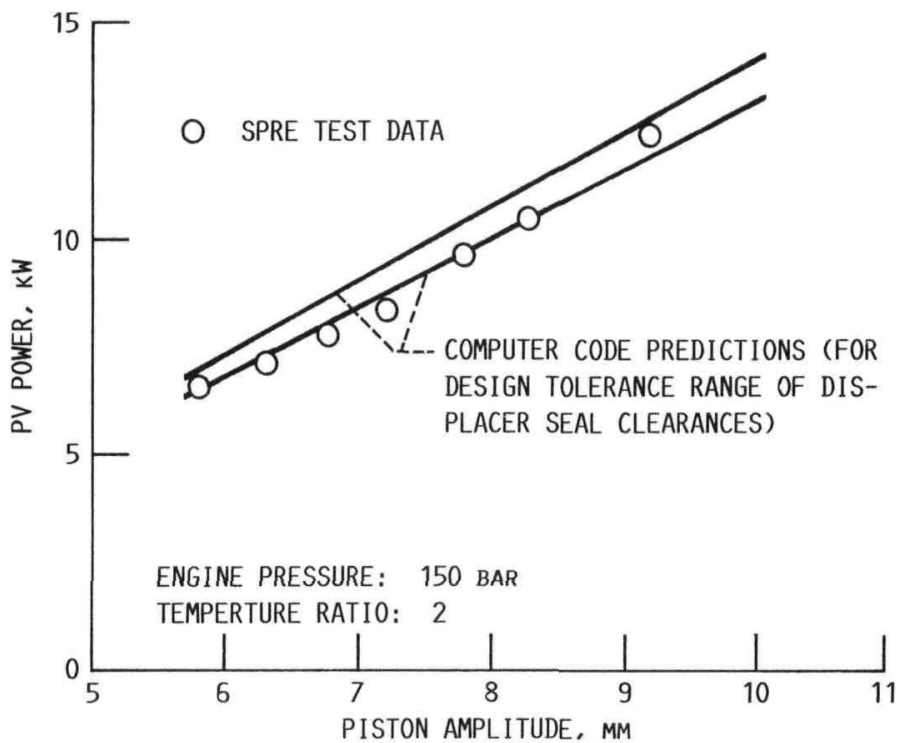

FIGURE 6. - PERFORMANCE OF SPRE-I. 


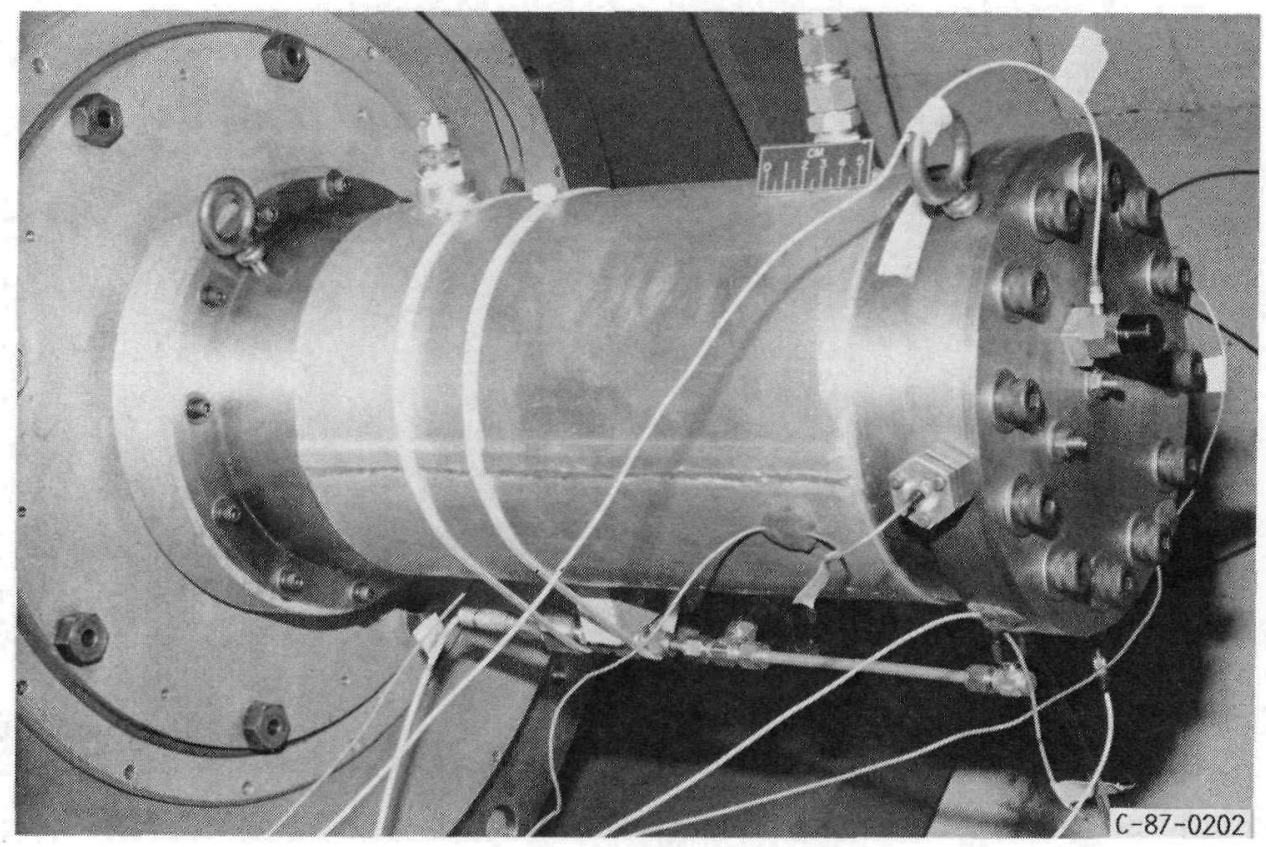

FIGURE 7. - VIBRATION ABSORBER FOR SPR ENGINES.

- alternator efFiciency is Significantly BelOW DESign (70 PERCENT VERSUS 93 PERCENT)

- flux leakage to surRounding structure at HIGH FREQUENCY IS INDICATED

- MEASUREMENTS at 100 heRTZ IDENTIFY LOSSES IN:

- cylinder

- joining Ring

- stators

- pRessuRe vessel

- plunger

- tuning capacitors
9.5 EFFICIENCY POINTS

9.3

6.3

5.5

4.2

0.2

- total measured efFiciency: POINT LOSSES 35

- engine/Alternator test efFiciency: POINT LOSSES 30 


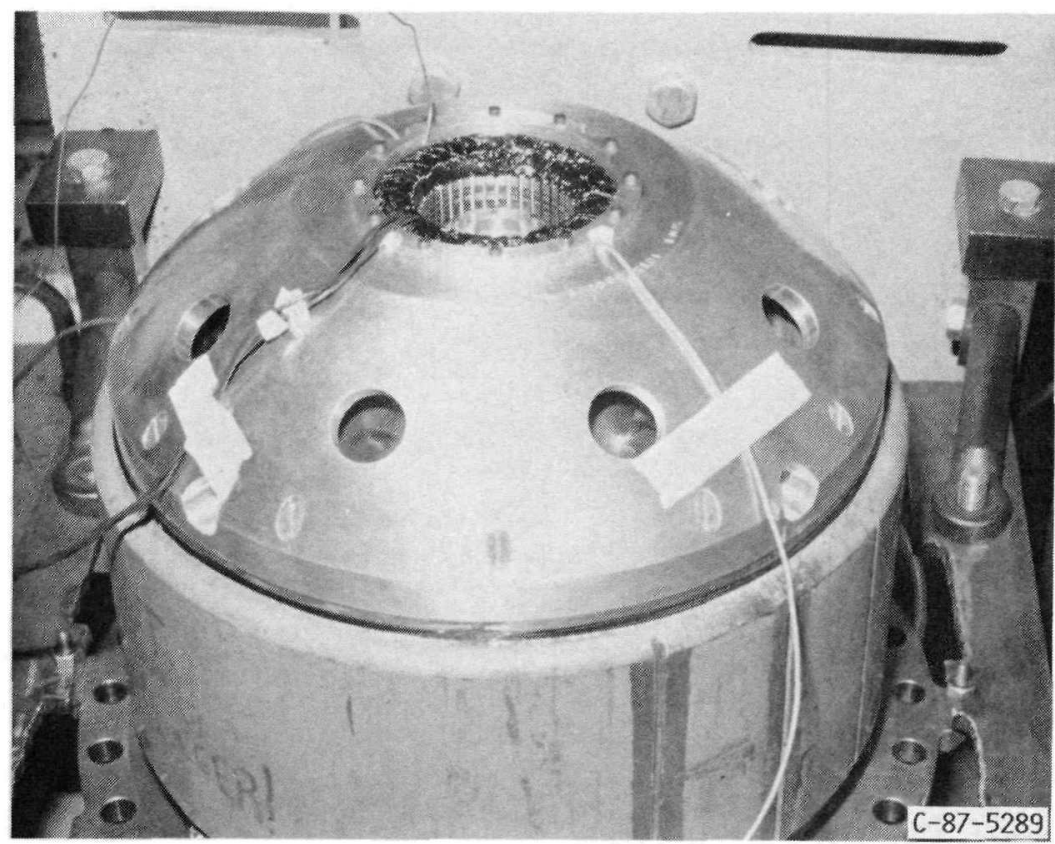

FIGURE 9. - TEST OF PISTON HYDRODYNAMIC BEARING OF SPRE-II IN AMBIENT AIR CONDITIONS.

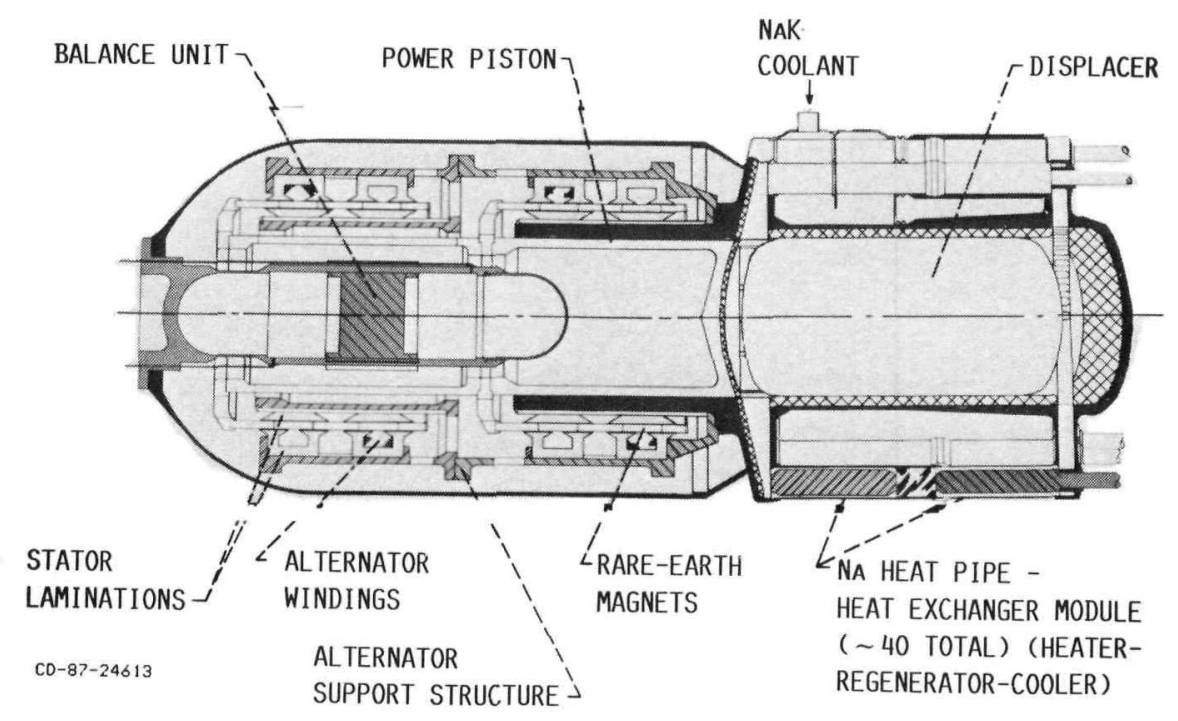

FIGURE 10. - EXPERIMENTAL STIRLING SPACE ENGINE. 
- FULLY-OPTIMIZED AND DESIGNED FOR SPACE POWER (LABORATORY VERSION)

- operation at superalloy temperatures apPropriate for space POWER - $\mathrm{T}_{\text {HOT }}$ AND $\mathrm{T}_{\text {COLD }}$

- alternator output power

- ENGINE SYSTEM EFFICIENCY

- heater temperature

- cooler temperature

- mean pressure (helium)

- OPERATING FREQUENCY

- SPECIFIC MASS

FIGURE 12. - CONCEPTUAL DESIGN PARAMETERS FOR THE 25 KWE ESSE.
$25 \mathrm{KWE}$

$30 \%$

1050 DEG K

525 DEG K

185 BAR

$90 \mathrm{~Hz}$

$5.5 \mathrm{KG} / \mathrm{KWE}$

- FACTOR OF 2 INCREASE IN POWER OUTPUT PER CYCLE.

FIGURE 11. - TECHNOLOGY ADVANCES OF THE ESS ENGINE DESIGN FROM THE SPD ENGINE DESIGN.

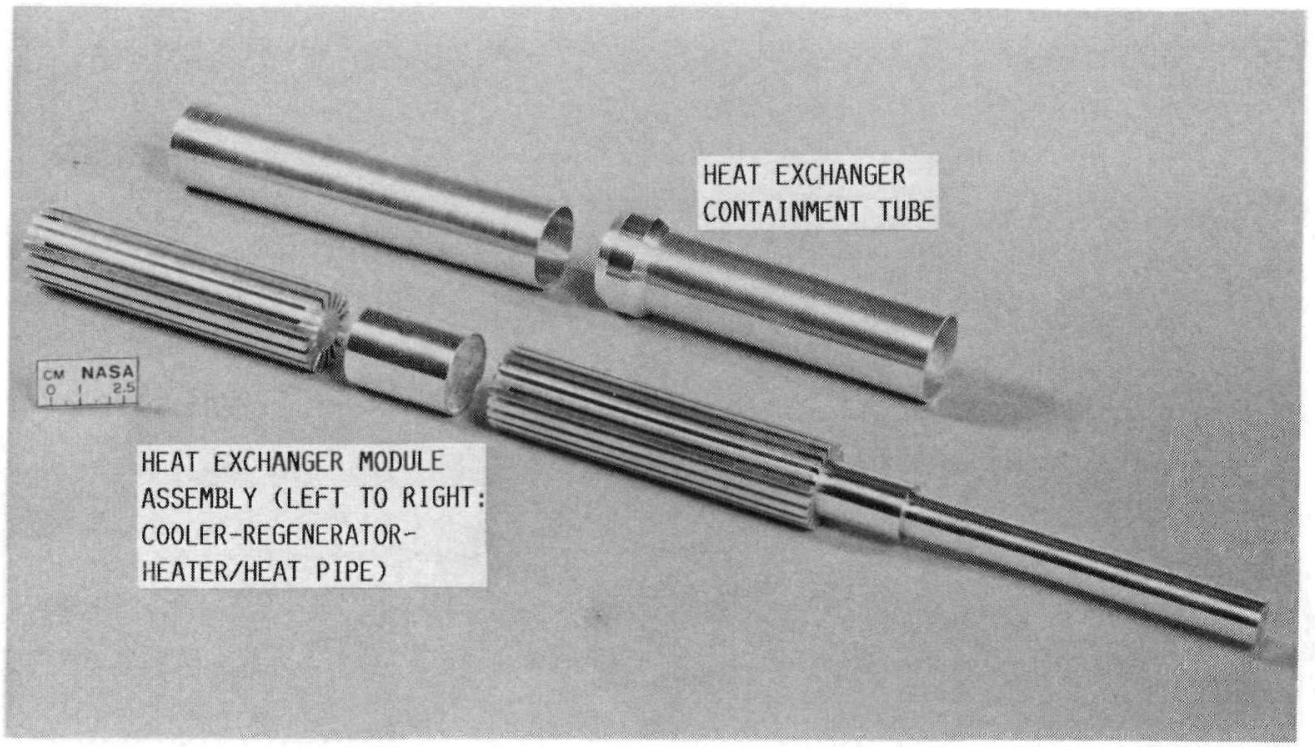

FIGURE 13. - TYPICAL ESS ENGINE HEAT EXCHANGER MODULE. 


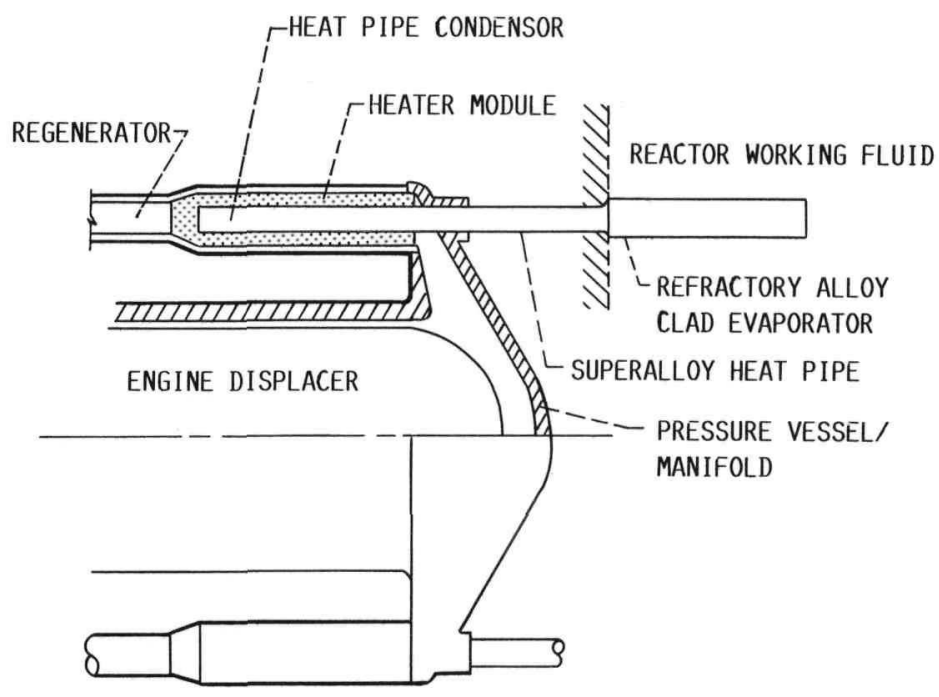

FIGURE 14. - CONCEPT FOR INTEGRATION OF HEAT PIPE INTO HEAT EXCHANGER MODULE.

- DETERMINE DESIGN FEASIBILITY OF SINGLE-CYLINDER FPSE-LA IN THE 150 kWE RANGE

- establish parameteric relationships

- percent carnot efFiciency Versus specific mass at TEMPERATURE RATIO AND POWER RANGE

- ASSESS PROMISing alternative StiRLing CONFIgURATIONS

- aWARD OPTIONS

- repeat study for alternate configuration

- conduct design of high pOWer system

- DETERMINE MAXIMUM POWER--BEYOND $150 \mathrm{kWE}$

FIGURE 15. - SPACE POWER FREE-PISTON STIRLING ENGINE SCALING STUDY. 


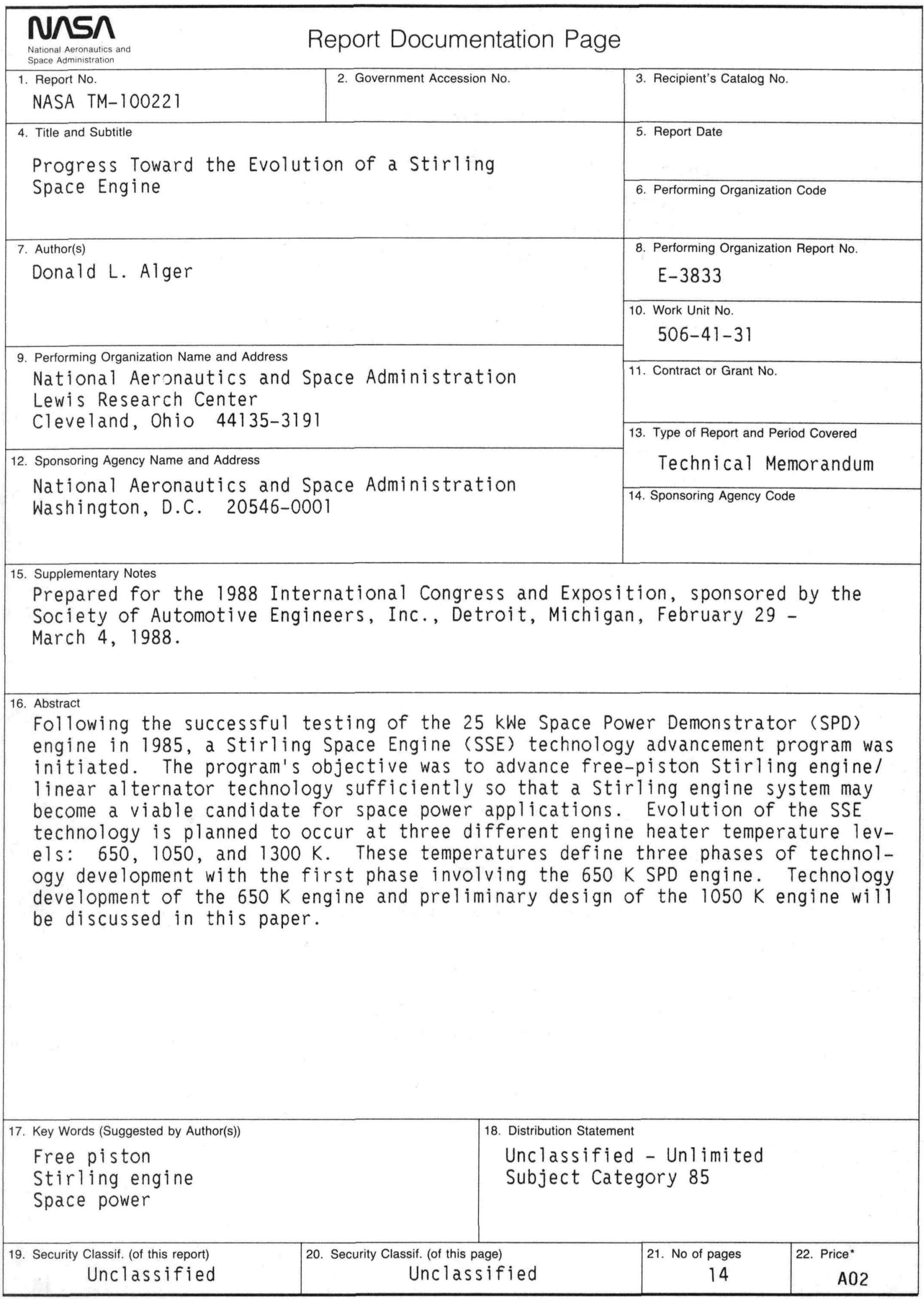

NASA FORM 1626 OCT $86 \quad$ *For sale by the National Technical Information Service, Springfield, Virginia 22161 
Lewis Research Center

ADDRESS CORRECTION REQUESTED

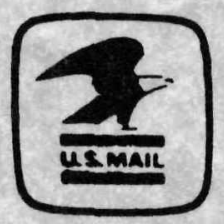

Official Business

Penalty for Private Use $\$ 300$

Postage and Fees Paid

National Aeronautics and

Space Administration

NASA-451 